\title{
The Ideology of Nuclear Order
}

\author{
Kjølv Egeland \\ Center for International Studies (CERI), Sciences Po, CNRS, Paris, France
}

\begin{abstract}
The "global nuclear order" is commonly understood as an evolving set of institutions, norms, and practices governing the development and use of nuclear technology worldwide. The pursuit of nuclear order is often portrayed as a "pragmatic" or "practical" compromise between unconstrained nuclear anarchy, on the one hand, and prompt steps toward nuclear disarmament, on the other. In this article, I use the tools of ideology critique to conceptualize the discourse and practices of nuclear order as a political ideology that has entrenched extant power structures and constrained the space for political action. While the ideology is formally wedded to the pursuit of the "sublime object" of a world without nuclear weapons, its underlying assumptions imply that the grand vision of abolition can never be realized in practice. To overcome the status quo, agents of change must subvert the ideology and repoliticize the nonproliferation and disarmament regime.
\end{abstract}

\begin{abstract}
"Australians have a reputation as pragmatists, not ideologues," asserted Canberra's delegation to the United Nations General Assembly (UNGA) in 2015. ${ }^{1}$ The occasion was the Australian government's snub of the proposed nuclear weapons ban treaty championed by the International Campaign to Abolish Nuclear Weapons (ICAN) and a growing number of nonnuclear-weapon states. Rejecting the proposed treaty as an expression of ideological, moralistic delusion, the Australians were keen to promote a "practical" and "pragmatic" step-by-step approach to nuclear disarmament instead. Australia was not alone. The French delegation said the ban-treaty proponents had adopted an "ideological approach that seeks to stigmatize and not to seek solutions. [...] The step-by-step approach is the only realistic approach." ${ }^{2}$ The US delegation, similarly, rejected the proposed treaty in favor of a "fullspectrum, pragmatic" strategy of incremental efforts at arms control. ${ }^{3}$ The Russian delegation insinuated that the proponents of a ban were driven by "a very dangerous illusion." ${ }^{4}$ The Chinese favored the assumption of a "rational and practical attitude" to facilitate "positive and pragmatic" negotiations. ${ }^{5}$
\end{abstract}

\footnotetext{
${ }^{1}$ Australia, UNGA First Committee, UN doc. A/C.1/70/PV.4. New York (October 12, 2015.

${ }^{2}$ France, UNGA First Committee, UN doc. A/C. 1/69/PV.3. New York (October 8, 2015).

${ }^{3}$ United States, UNGA First Committee, UN doc. A/C. 1/70/PV.4. New York (October 12, 2015).

${ }^{4}$ Russia, UNGA First Committee, UN doc. A/C. 1/70/PV.26. New York (November 6, 2015).

${ }^{5}$ China, UNGA First Committee. UN doc. A/C.1/70/PV.18. New York (October 27, 2015).
} 
I argue that these appeals to a non-ideological, "practical" nuclear politics are ideological statements par excellence. They belie what one theorist calls an "end-of-ideology ideology" - a doxastic world conceived as natural and unmediated by those within it. ${ }^{6}$ As Louis Althusser puts it, "those who are in ideology believe themselves by definition outside ideology."7 In this paper, I argue that the continuous rebuilding of nuclear arsenals is perpetuated, in part, by what I term the ideology of nuclear order. Expressed through expert discourse and diplomatic practice, the ideology frames humanity as teetering on the brink of nuclear disarray. At the same time, however, the ideology conceives virtually any political or institutional change as perilous, thus resigning the diplomatic process to an endless recycling of the careful managerial "solutions" that have already been promoted, with limited or no success, for decades. While the ideology frames the abolition of nuclear weapons as a long-term "vision," it simultaneously portrays the practice of nuclear deterrence by "responsible" major powers as legitimate and necessary for stability and order in the short term, thus undermining the cause of disarmament. The ideology has dominated the political discourse on nuclear policy in the nuclear-armed states and most of their allies for half a century, but also shapes multilateral diplomatic practices, media narratives, and, by extension, global politics.

Tracing the rise of the ideology of nuclear order to the 1960s, this article answers Benoît Pelopidas' invitation to rethink the 1960 s as a decade in which the future direction of history was constrained, as opposed to the standard narrative of the 1960s as a decade of emancipation. ${ }^{8}$ Specifically, I endeavor to connect the scholarship on global nuclear politics with the theoretical literature on ideology. Ideology critique, I argue, adds an important layer to the nascent literature on hegemony and contests of legitimacy in multilateral nuclear diplomacy by clarifying some of the key mechanisms linking structural factors such as norms and discourses to behavioral outcomes. The ideology lens helps illuminate a range of otherwise puzzling phenomena, including the imperviousness of mainstream nuclear discourse and policy practice to critique and contrary evidence, ${ }^{9}$ the perpetuation of the prevailing nuclear order in spite of widespread cynicism about the major powers' commitment to its formal ideals, the hostility toward the Treaty on the Prohibition of Nuclear Weapons (TPNW) by actors that nominally support nuclear disarmament, and the inability of mainstream nuclear policy analysis to come up with new ideas. ${ }^{10}$ Ideology critique also helps clarify how and why certain disarmament initiatives are seen as subversive while others are embraced as supplements to the status quo.

This is not the first article to introduce the concept of ideology to nuclear security studies. Several analysts of global nuclear politics have touched on the concept of ideology in passing or encouraged others to cross-fertilize the literatures on ideology and nuclear nonproliferation and disarmament. ${ }^{11}$ The concept of ideology is also frequently used in both scholarly and diplomatic discourse to discredit opponents as

\footnotetext{
${ }^{6}$ Terry Eagleton, Ideology: An Introduction (London: Verso, 1991), pp. 4, 58.

${ }^{7}$ Louis Althusser, On the Reproduction of Capitalism, G.M. Goshgarian, trans. (London: Verso, 2014), p. 181.

${ }^{8}$ Benoit Pelopidas, "The Birth of Nuclear Eternity," forthcoming in Futures, eds. Sandra Kemp and Jenny Andersson (Oxford: Oxford University Press, 2021).

${ }^{9}$ See Benoît Pelopidas, "The Unbearable Lightness of Luck," European Journal of International Security 2:2 (2017), pp. 240-62.

${ }^{10}$ Carina Meyn, "Realism for Nuclear-Policy Wonks," Nonproliferation Review 25:1-2 (2018), pp. 111-28.

${ }^{11}$ E.g. Nick Ritchie, "A Hegemonic Nuclear Order," Contemporary Security Policy 40:4 (2019), pp. 409-34; William Chaloupka, Knowing Nukes (Minneapolis, MN: University of Minnesota Press, 1992), p. 1; E. P. Thompson, "Notes on Exterminism, the Last Stage of Civilization," New Left Review 121 (1982), pp. 3-31.
} 
delusional or out of touch. ${ }^{12}$ Others have successfully deployed ideology critique to certain aspects of global nuclear order, most notably to analyze orientalist discourses of nuclear proliferation and to understand the way in which weapons are fetishized as (masculine) status objects. ${ }^{13}$ In this article, I use the concept of ideology as an analytical category to illuminate the discourses and practices of nuclear ordering as such. The ambition is to provide a broad analytical framework that could serve as a launch pad for further investigations into the ideological underpinnings of nuclear policy.

In this article, ideology is understood as the "imaginary maps" people rely on to make sense of, and act in, the world. ${ }^{14}$ An ideology, in this view, is simultaneously "constituted" by a set of factual and normative claims (substance) and "constitutive" of a certain way of viewing and acting in the world (form). This understanding departs from traditional conceptions of ideology as either "delusion," as in the early Marxian notion of "false consciousness," or a stringent and consciously held value system, as in the rationalist conception of political ideologies. ${ }^{15}$ Ideologies are not necessarily either "delusions" or wittingly held normative commitments. As understood here, ideologies provide a set of heuristic shortcuts, assumptions, and ideational coordinates that allow individuals to navigate the complexities of the world and its politics. ${ }^{16}$ The primary task of ideology critique, in this view, is not to compare normative systems or to reveal an unmediated "Truth" or "Reality," but rather to uncover and litigate the imaginary maps that reproduce social arrangements.

The article proceeds in six steps. First, I discuss the emergence of the institutions and practices that are today referred to as the "nuclear order." Second, I conceptualize nuclear order as an ideology, identifying its substantive content through a close reading of five op-eds by a group of high-profile nuclear pundits. Third, drawing on theories of ideology, I pinpoint "the vision of peace and security in a world without nuclear weapons" as the ideology's "sublime object," to wit, its overarching discursive justification and the ideal toward which the community nominally strives. Fourth, I discuss the ideology's constitutive assumptions about human nature and anarchy, demonstrating how the naturalisms of nuclear "desire" and "power" have fostered an acute concern with stability and nonproliferation over alternative aspirations such as justice and disarmament. Fifth, I identify the nuclear order's ideological apparatus of enforcement. The "nonproliferation complex" and institutional architecture for nuclear nonproliferation and disarmament discredit attempts at change and inadvertently produce nuclear weapons as symbols of power and prestige. Lastly, I discuss the intended subversion of the ideology of nuclear order by the architects of the TPNW.

\section{The Emergence and Consolidation of Nuclear Order}

The invention of atomic and thermonuclear weapons provoked a wide range of proposals for the management of nuclear technology. The 1940s and 1950s saw renowned scholars

\footnotetext{
${ }^{12}$ See e.g. Joachim Krause, "Enlightenment and Nuclear Order," International Affairs 83:3 (2007), p. 485.

${ }^{13}$ Hugh Gusterson, "Nuclear Weapons and the Other in the Western Imagination," Cultural Anthropology 14:1 (1999), pp. 111-43; Anne Harrington de Santana, "Nuclear Weapons as the Currency of Power," Nonproliferation Review 16:3 (2009), pp. 325-45; Shampa Biswas, Nuclear Desire (Minneapolis: University of Minnesota Press, 2014), pp. 117, 124-25.

${ }^{14}$ Eagleton, Ideology, 152.

${ }^{15}$ Eagleton, Ideology, pp. 1-7.

${ }^{16}$ Althusser, On the Reproduction of Capitalism, p. 265.
} 
and diplomats advocate a range of diverse and radical solutions, including world government, comprehensive nuclear disarmament, and multilateral ownership or decentralization of the possession of nuclear weapons. ${ }^{17}$ However, over the course of the late 1950s and early 1960s, opinion in the US national security establishment converged on the idea of navigating between the supposed extremes of unrestrained nuclear anarchy, on the one hand, and nuclear abolition and world government, on the other. Security, so went the argument, would be best served through the implementation of vigilant practices of deterrence, cautious arms control measures, and the extension of security assurances to allies. ${ }^{18}$ Anything else, so went the argument, was impractical or unfeasible. The result was the fashioning of the evolving constellation of norms, institutions, and security practices commonly referred to as the "global nuclear order."19 Of course, the alleged superior feasibility of a "third way" nuclear order was and remains a political bet. So-called "nuclear realists," including Lewis Mumford, Günther Anders, and Bertrand Russell, insisted that the long-term prospects of a nuclear-armed world were bleak; any "order" or "stability" would prevail only until suddenly all was lost. ${ }^{20}$ Recent scholarship has confirmed that the avoidance of nuclear war and unintended nuclear weapon explosions since 1945 has been accomplished, in part, through sheer luck. ${ }^{21}$

While the Soviet Union and several nonaligned states helped shape what is today referred to as nuclear order, the US government was its key architect. According to one analyst, the US-led establishment of nuclear order reflected a symbiosis of "constitutional, balance of power, and hegemonic strategies." ${ }^{22}$ In this perspective, the order gave body to a "strategic narrative" that allowed US elites to promote a shared meaning of the past, present, and future of global nuclear governance so as to "shape the opinions and behavior of actors at home and overseas." ${ }^{23}$ Adopted in 1968 and widely conceived as the cornerstone of the nascent order $^{24}$ the Nuclear Nonproliferation Treaty (NPT) prohibited "non-nuclear-weapon States" from acquiring nuclear weapons, obliged "nuclear-weapon States" not to disseminate such weapons to others, and committed all to pursue disarmament negotiations while simultaneously guaranteeing an inalienable right to use nuclear technology for peaceful purposes. To classify states as either "nuclear" or "nonnuclear," the drafters of the NPT drew a distinction between the states that had carried out a nuclear test explosion by January 1967 and the rest. However, in the traditional view, the establishment of a hierarchical nuclear order that restricted access to nuclear arms for all but a handful of major powers "rested heavily upon the notion that the possession of nuclear weapons by the five acknowledged

\footnotetext{
${ }^{17}$ Daniel Deudney, "The Great Debate," in The Oxford Handbook of International Security, eds. Alexandra Gheciu and William C. Wohlforth (Oxford: Oxford University Press, 2018), pp. 334-49; Grégoire Mallard, Fallout: Nuclear Diplomacy in an Age of Global Fracture (Oxford: Oxford University Press, 2014).

${ }^{18}$ Emanuel Adler, "The Emergence of Cooperation," International Organization 46:1 (1992), pp. 101-45; Pelopidas, "The Birth of Nuclear Eternity."

${ }^{19}$ William Walker, A Perpetual Menace (London: Routledge, 2012); Michal Smetana, Nuclear Deviance (Cham: Palgrave Macmillan, 2020), p. 93; Nicola Horsburgh, China and Global Nuclear Order (Oxford: Oxford University Press, 2015), p. 59.

${ }^{20}$ Rens van Munster and Casper Sylvest, Nuclear Realism (Abindgon: Routledge, 2016).

${ }^{21}$ Pelopidas, "The Unbearable Lightness of Luck"; Patricia Lewis et al., Too Close for Comfort (London: Chatham House, 2014).

${ }^{22}$ William Walker, "Weapons of Mass Destruction and International Order to 1990," Adelphi Papers 44:370 (2004), p. 30.

${ }^{23}$ Alister Miskimmon, Ben O'Loughlin, and Laura Roselle, Strategic Narratives (Abingdon: Routledge, 2013), p. 176.

${ }^{24}$ See e.g. Kutchesfahani, Global Nuclear Order; Ursula Jasper, "Dysfunctional, but Stable - a Bourdieuian Reading of the Global Nuclear Order," Critical Studies on Security 4:1 (2016), pp. 42-56; Tanya Ogilvie-White, "Great Power Responsibility and Nuclear Order," The Nonproliferation Review 20:1 (2013), pp. 173-77.
} 
powers was a temporary trust." ${ }^{25}$ But it also rested on lingering colonial structures. While the "nuclear-weapon states" were all empires and major powers, the (former) colonies and indigenous communities that often supplied their uranium ore or (unwillingly) suffered the worst consequences of their nuclear testing programs were defined as "nonnuclear" and subordinate. ${ }^{26}$

The durability of the nuclear order that came into being in the 1960s and 1970s was not obvious at the time of its creation. A range of experts predicted that a failure of the major nuclear powers to level the hierarchy by eliminating their nuclear weapons would soon lead to a wave of proliferation and/or a disintegration of the inchoate nonproliferation regime. $^{27}$ Peering into the future, many of the mid-20th century's most renowned international thinkers foretold that the coming decades would bring either nuclear pandemonium or the transition to a new mode of global governance. ${ }^{28}$ They were, in other words, highly skeptical about the wisdom and stability of any nuclear order that attempted to combine asymmetric distribution of world-ending weapons with an international system of sovereign states. Few predicted what would in fact turn out to be the case - that the nuclear order that emerged in the late 1960s would be perpetuated relatively unchanged for half a century and counting. Global nuclear politics continues to be played out by sovereign states and remains divided between a small group of nuclear "haves" and a large group of "have-nots." All but a handful of the world's states now subscribe to the NPT.

How, then, was the nuclear order stabilized? Mainstream accounts of continuity and change in nuclear politics stress the importance of geopolitical factors, technological advances, and knowledge. ${ }^{29}$ Yet, neither changes to the so-called security environment (détente, the Second Cold War, and the end of the Cold War), nor dramatic technological developments (advances in computing power; remotesensing), nor startling findings by scholars (the climatic effects of nuclear war; evidence about nuclear close calls) have engendered major political changes. If anything, the range of proposals promoted by the most influential states, organizations, and scholars has narrowed considerably over time. ${ }^{30}$ While world government and premeditated dissemination of nuclear weapons have long since been pushed out of the nuclear-political Overton window, disarmament functions largely as an empty rhetorical signifier. Admittedly, the number of nuclear warheads in the world has decreased substantially since the peak in 1986. But there are still more than enough nuclear weapons in the world to produce catastrophic nuclear winter, ${ }^{31}$ and the nine nuclear-armed states are all in the process of perpetuating and modernizing

\footnotetext{
${ }^{25}$ William Walker, "Nuclear Order and Disorder," International Affairs 76:4 (2000), p. 708.

${ }^{26}$ See Gabrielle Hecht, Being Nuclear: Africans and the Global Uranium Trade (Cambridge, MA: MIT Press, 2012); Ritu Mathur, "Sly Civility and the Paradox of Equality/Inequality in the Nuclear Order," Critical Studies on Security 4:1 (2016), pp. 57-72.

${ }^{27}$ See e.g. Thomas A. Halsted, "The Spread of Nuclear Weapons," Bulletin of the Atomic Scientists 31:5 (1975), p. 11; Lincoln P. Bloomfield, "Nuclear Spread and World Order," Foreign Affairs 53:4 (1975), pp. 743-55; Hedley Bull, "Rethinking NonProliferation," International Affairs 51:2 (1975), p. 177; William Epstein, The Last Chance (London: The Free Press, 1976), p. 256.

${ }^{28}$ Van Munster and Sylvest, Nuclear Realism; Campbell Craig, Glimmer of a New Leviathan (New York, NY: Columbia University Press, 2003)

${ }^{29}$ See e.g. George Perkovich and James M. Acton, "Abolishing Nuclear Weapons," Adelphi Papers 48:396 (2008), p. 25.

${ }^{30}$ Pelopidas, "The Birth of Nuclear Eternity."

${ }^{31}$ Joshua Coupe et al., "Nuclear Winter Responses to Nuclear War Between the United States and Russia," Journal of Geophysical Research: Atmospheres 124:15 (2019), pp. 8522-43.
} 
their nuclear armories. ${ }^{32}$ And after more than fifty years, none of the myriad of diplomatic steps and solutions associated with the pursuit of a "step-by-step" thirdway nuclear order have been completed (a comprehensive ban on nuclear testing, a ban on the production of fissile material for nuclear weapons, a shift to no-first-use postures, transparency and accounting of existing stocks, and ultimately the devaluing and elimination of nuclear-weapon programs).

\section{Nuclear Order as Ideology}

The concept and practices of nuclear order have been most attentively investigated by William Walker. He conceptualizes nuclear order as a normative edifice resting on interrelated systems of nuclear "abstinence" and "deterrence." ${ }^{33}$ More specifically, nuclear order comprises "evolving patterns of thought and activity that serve primary goals of world survival, war avoidance and economic development; and the quest for a tolerable accommodation of pronounced differences in the capabilities, practices, rights and obligations of states." ${ }^{34}$ "Nuclear order," in other words, describes the dominant elite discourse of nuclear governance and war avoidance and the embodiment of this discourse in institutions, norms, and practices.

I contend that Walker's definition of nuclear order could substitute straightforwardly as a definition of ideology. Indeed, ideologies are evolving cultural patterns that serve primary goals. As discussed above, ideologies are "imaginary maps" that shape the identities and behavior of individuals and groups. ${ }^{35}$ Below, I argue that the discourse and practices of nuclear order display all the hallmarks of a political ideology: (i) a distinctive assemblage of substantive claims and commitments, (ii) "a sublime object" that justifies extant political arrangements, (iii) bedrock assumptions or "naturalisms" about how the world works, (iv) a compliance-fostering "apparatus," and (v) lingering tension between spoken and unspoken rules and principles. My understanding of nuclear order as ideology thus builds on the work of Walker - nuclear order is understood here as the evolving set of activities, institutions, and discursive commonplaces that structures nuclear politics - but departs from it in at least one crucial respect. While Walker's focus on the formal principles of nuclear governance leads him to conceptualize the order-building project as a liberal enlightenment movement genuinely geared toward nuclear abolition, ${ }^{36}$ ideology critique leads to a conclusion that the discourse and practices of nuclear ordering serve largely as checks on change. That said, I do not claim that all authors who subscribe to the views laid out below are engaged in a deliberate effort to buttress extant power structures or are disingenuous in their support for eventual nuclear disarmament. My claim is rather that the ideology's explicit goal of abstinence is in practice undercut by the ideology's own assumptions about human nature and political change.

\footnotetext{
${ }^{32}$ Hans M. Kristensen and Matt Korda, "Status of World Nuclear Forces," Federation of American Scientists (May 2019), available online at: https://fas.org/issues/nuclear-weapons/status-world-nuclear-forces/.

${ }^{33}$ Walker, "Nuclear Order and Disorder," p. 703.

${ }^{34}$ Walker, A Perpetual Menace, p. 12.

${ }^{35}$ Althusser, On the Reproduction of Capitalism, p. 262; Eagleton, Ideology, p. 152.

${ }^{36}$ William Walker, "Nuclear Enlightenment and Counter-Enlightenment," International Affairs 83:3 (2007), pp. 431-53.
} 
In recent years, arguably the most prominent spokespersons of what I refer to here as the ideology of nuclear order have been a group of retired American policymakers. Between 2007 and 2013, George Shultz, William Perry, Henry Kissinger, and Sam Nunn published a series of five op-eds on nuclear policy in the Wall Street Journal. ${ }^{37}$ Issued by a group that, in the words of one commentator, gave off a "bipartisan or nonpartisan sheen, ${ }^{38}$ the op-eds were widely celebrated in both expert and popular discourse as a rearticulation of common sense and reason. ${ }^{39}$ The quartet argued that the spread of nuclear weapons was "accelerating" and that nuclear deterrence was becoming less effective. "We face a very real possibility that the deadliest weapons ever invented could fall into dangerous hands," they added. It was therefore important to "reassert the vision" of a world without nuclear weapons. ${ }^{40}$ Likening nuclear disarmament to "the top of a very tall mountain," the four mused that "we can't even see the top of the mountain [...]. But the risks from continuing to go down the mountain or standing pat are too real to ignore. We must chart a course to higher ground where the mountaintop becomes more visible. ${ }^{\prime \prime 1}$ On specific policy, the four encouraged the US government to seek entry-intoforce of the 1996 Comprehensive Nuclear-Test-Ban Treaty (CTBT) to negotiate further nuclear stockpile reductions with Russia, to enhance the safety of nuclear arsenals and materials, to champion negotiations on a prohibition of the production of fissile material for nuclear weapons, to move "toward a new and more stable form of deterrence," and to invest in a "modernized nuclear weapons infrastructure." ${ }^{42}$

The newspaper op-eds by the "four horsemen" have usually been interpreted as progressive interventions that challenged dogmas and "revitalized the topic of nuclear disarmament" in the international community. ${ }^{43}$ I argue that, far from strengthening the cause of disarmament, the op-eds merely restated the key tenets of the ideology of nuclear order. These tenets, I claim, are both produced by and constitutive of a distinctive worldview. Its central claims and commitments may be summarized as follows:

- "The vision of moving to zero" "44. First, nuclear disarmament is presented as an important objective, but simultaneously as a long-term project or "vision" beyond the international community's immediate grasp. As we cannot yet see the

\footnotetext{
${ }^{37}$ A sixth op-ed, by three of the "four horsemen", was published in 2019.

${ }^{38}$ Philip Taubman, The Partnership (New York, NY: Harper Collins, 2012), p. 422.

${ }^{39}$ See e.g. Eben Harrell, "The Four Horsemen of the Nuclear Apocalypse," Time (May 20, 2011), available online at: https:// science.time.com/2011/03/10/the-four-horsemen-of-the-nuclear-apocolypse/; J. Peter Scoblic, "Disarmament Redux," Bulletin of the Atomic Scientists 64:1 (2008), pp. 34-39.

${ }^{40}$ George Shultz, William Perry, Henry Kissinger, and Sam Nunn, "A World Free of Nuclear Weapons," Wall Street Journal (January 4, 2007), available online at: https://media.nti.org/pdfs/NSP_op-eds_final_.pdf.

${ }^{41}$ George Shultz, William Perry, Henry Kissinger, and Sam Nunn, "Toward a Nuclear-Free World," Wall Street Journal (January 16, 2008), available online at: https://media.nti.org/pdfs/NSP_op-eds_final_.pdf.

${ }^{42}$ Shultz et al., "A World Free of Nuclear Weapons"; Shultz et al., "Toward a Nuclear-Free World"; George Shultz, William Perry, Henry Kissinger, and Sam Nunn, "How to Protect Our Nuclear Deterrent," Wall Street Journal (January 20, 2010), available online at: https://media.nti.org/pdfs/NSP_op-eds_final_.pdf; George Shultz, William Perry, Henry Kissinger, and Sam Nunn, "Deterrence in the Age of Nuclear Proliferation," Wall Street Journal (March 7, 2011), available online at: https://media.nti.org/pdfs/NSP_op-eds_final_.pdf; George Shultz, William Perry, Henry Kissinger, and Sam Nunn, "Next Steps in Reducing Nuclear Risks," Wall Street Journal (March 5, 2013), available online at: https://www.wsj.com/articles/ SB10001424127887324338604578325912939001772.

${ }^{43}$ Martin Senn and Christoph Elhardt, "Bourdieu and the Bomb," European Journal of International Relations 20:2 (2014), p. 316; Taubman, The Partnership.

${ }^{44}$ Shultz et al., "Toward a Nuclear-Free World."
} 
"mountaintop" of abolition, we must continue our current course until the summit becomes "more visible." 45 Disarmament is recurrently presented as a shared, apolitical goal that all states already agree on, meaning that disarmament work is equated with polite, technocratic deliberations about implementation. The nuclear-armed states' ceaseless nuclear modernization programs and routine disregard for nominally agreed-upon disarmament roadmaps - such as the communiqués adopted by NPT Review Conferences - are either ignored or brushed aside as temporary glitches.

- "Protect our nuclear deterrent" ${ }^{46}$ : Second, pending the achievement of disarmament, nuclear deterrence is framed as an essential and objective precondition for international security and stability. In the words of Shultz et al., the United States must maintain and protect its nuclear arsenal, "whatever its size, for as long as the nation's security requires it." ${ }^{47}$ Arms control measures and force restructurings must first and foremost deliver a "stable form of deterrence." ${ }^{48}$ By implication, the perceived security interests of the nuclear powers are presented "as if they were equally beneficial to all nations of the globe." ${ }^{49}$

- "Prevent their spread"50: Third, while nuclear energy is framed as instruments of modernity and post-scarcity, ${ }^{51}$ nonproliferation of "military" nuclear technology is presented as a vital imperative for "world security." ${ }^{152}$ Distinguishing between fit and unfit possessors of nuclear arms, the ideology implicitly calls on "responsible" states to deter "rogue" states and make special efforts to keep nuclear material out of particularly "dangerous hands." 53 The states implicitly defined as "nuclear-weapon states" by the NPT are typically described as "official," "legal," or "legitimate" nuclearweapon powers.

- "On the precipice of a new and dangerous nuclear era" ${ }^{54}$ : Fourth, the present and near-term future are usually portrayed as uniquely dangerous. Nuclear order, in turn, is typically represented as being under severe strain or even on the verge of total collapse. In their op-eds, Shultz et al. assert that the nonproliferation regime is eroding, that the risk of nuclear weapons being used is rising, that deterrence relations are "increasingly unstable," that nonnuclear-weapon states are growing "increasingly skeptical" of the nuclear-armed states' disarmament promises, and that nuclear proliferation is already "accelerating," pushing international society to a "tipping point. ${ }^{155} \mathrm{New}$ arms races, proliferation crises, and disruptive technological innovations are forever just around the corner.

- "A series of practical steps": Fifth, and in some tension with their disconsolate framing of the present and near-term future, those within the ideology of nuclear order are invariably optimistic about solving the nuclear predicament by means of the "practical" or "pragmatic" diplomatic approaches and proposals that have

\footnotetext{
${ }^{45}$ Ibid.

${ }^{46}$ Shultz et al., "How to Protect Our Nuclear Deterrent."

${ }^{47}$ Ibid.

${ }^{48}$ Shultz et al., "Deterrence in the Age of Nuclear Proliferation."

${ }^{49} \mathrm{Cf}$. Gusterson, "Nuclear Weapons and the Other," p. 132.

${ }^{50}$ Shultz et al., "Toward a Nuclear-Free World."

${ }^{51}$ See Columba Peoples, "Life in the Nuclear Age," Journal of International Political Theory 15:3 (2019), pp. $279-96$.

${ }^{52}$ Shultz et al., "A World Free of Nuclear Weapons."

${ }^{53} \mathrm{lbid}$.

${ }^{54}$ Ibid.

${ }^{55}$ Ibid.; Shultz et al., "Toward a Nuclear-Free World"; Shultz et al., "Next Steps."
} 
already been championed, with limited or no success, since the 1960s or earlier. Decade after decade, measures such as the CTBT, a fissile material treaty, transparency measures, and no-first use policies are upheld as new solutions to "revitalize" the disarmament agenda. The common feature of these proposals is that they seek to incrementally reduce the salience of nuclear weapons while at the same time ensuring, or at any rate accepting, the continued legitimacy and operation of nuclear deterrence. Proposals that go against these precepts are strongly discouraged. In Walker's words, "no other effective and legitimate nuclear order, let alone security order, is imaginable or capable of realization. [...] The only alternative is a highly conflictual and destructive disorder." ${ }^{\prime 56}$

This assemblage of partly contradictory claims and injunctions, I argue, makes up the substantive content of the ideology of nuclear order. Offering both descriptive and prescriptive judgments, the five notions identified above are present in an enormous body of policy-oriented literature on nuclear nonproliferation, strategy, and disarmament, as well as mainstream media reports and the official statements of the nucleararmed states and most of their allies. Recent interventions that display all or most of the five include as diverse texts as the Bulletin of the Atomic Scientists' 2020 Doomsday Clock press release, ${ }^{57}$ the 2019 Stockholm declaration on nuclear disarmament and the Nonproliferation Treaty, ${ }^{58}$ The Elders' 2019 pamphlet on nonproliferation and disarmament, ${ }^{59}$ the 2019 report of the Munich Security Conference, ${ }^{60}$ the UK House of Lords' 2019 inquiry into the NPT and nuclear disarmament, ${ }^{61}$ the UN Secretary General's 2018 agenda for disarmament, ${ }^{62}$ and the Trump Administration's 2018 Nuclear Posture Review. ${ }^{63}$ As noted above, those within the ideology of nuclear order habitually identify the present and near-term future as unacceptably or increasingly dangerous, but nevertheless refrain from challenging the legitimacy or alleged necessity of nuclear deterrence, embracing instead the traditional step-by-step approach to disarmament. Yet the so-called "pragmatic" or "practical" step-by-step approach has not only failed to deliver practical results - what is usually considered the very first "step," the CTBT, is yet to be completed - the pursuit of this approach over a period of several decades has presumably played a key role in producing the supposedly unacceptable present. The denial of contradiction, Anthony Giddens points out, is a standard feature of political ideologies. ${ }^{64}$

\footnotetext{
${ }^{56}$ Walker, "Nuclear Order and Disorder," p. 704.

${ }^{57}$ Bulletin of the Atomic Scientists, "Press Release - It Is Now 100 Seconds to Midnight" (January 23, 2020), available online at: https://thebulletin.org/2020/01/press-release-it-is-now-100-seconds-to-midnight/.

${ }^{58}$ Swedish Ministry of Foreign Affairs, "The Stockholm Ministerial Meeting on Nuclear Disarmament and the NonPorliferation Treaty" (June 11, 2019), available online at: https://www.government.se/statements/2019/06/thestockholm-ministerial-meeting-on-nuclear-disarmament-and-the-nonproliferation-treaty/.

${ }^{59}$ The Elders, "Nuclear Non-Proliferation and Disarmament" (2019), available online at: https://theelders.org/programmes/ nuclear-nonproliferation-and-disarmament.

${ }^{60}$ Munich Security Conference. "The Great Puzzle" (2019), available online at: https://www.securityconference.de/en/ publications/munich-security-report/.

${ }^{61}$ UK House of Lords, "Rising Nuclear Risk, Disarmament and the Nuclear Non-Proliferation Treaty," London (April 24, 2019).

${ }^{62}$ United Nations, Securing Our Common Future (New York, NY: Office for Disarmament Affairs, 2018).

${ }^{63}$ US Department of Defense, Nuclear Posture Review (Arlington, VA: Office of the Secretary of Defense, 2018).

${ }^{64}$ Anthony Giddens, Central Problems in Social Theory (Basingstoke: Palgrave Macmillan, 1979), p. 194.
} 


\section{Cynical Reason and the Sublime Object of Nuclear Order}

Ideologies are often argued to be defined by their "sublime objects." Sublime objects "liberty," "the national interest," "the communist society," etc. - provide overarching discursive justifications for political arrangements, an overarching aspiration or ideal that binds the political community as such. In one theorist's view, sublime objects of ideology must be powerful enough to elicit devotion, but simultaneously vague enough to allow people to project into them their own interests and concerns. Hence, a sublime object of ideology is a "signifier without a signified," and can "persist only in an interspace, in an intermediate state, viewed from a certain perspective, half-seen" - as a mountaintop shrouded in clouds. ${ }^{65}$ I suggest that the sublime object of the ideology of nuclear order is the goal of achieving peace and security in a world without nuclear weapons. Emotionally powerful but largely undefined, the project of disarmament offers a hortatory destination on which all states nominally agree. Indeed, virtually all the world's governments, including those with the largest nuclear arsenals, routinely express their devotion to the goal of nuclear abolition. Barack Obama famously proclaimed his country's commitment "to seek the peace and security of a world without nuclear weapons" in Prague in April 2009. ${ }^{66}$ Making an exception to his otherwise determined effort to controvert his predecessor, Donald Trump echoed Obama's Prague speech multiple times during his presidency, asserting that a world without nuclear weapons would be the "ultimate" deal and that the world's states should seek to "end nuclear weapons" across the globe. ${ }^{67}$ Yet the goal of a world free of nuclear weapons is often framed as so distant and abstract that virtually any policy can be said to support or oppose it. In a particularly striking example, Japan's official rejection of the 2017 TPNW was based on the Japanese government's assertion "that the treaty that was adopted this time differs from our view and approach, which is aimed at 'a world free of nuclear weapons.'"'68

As other sublime objects of ideology, the clouded mountaintop of nuclear abolition serves political functions. Tellingly, the major power's legal commitment to disarmament came about through the adoption of the NPT - as a mostly symbolic quid pro quo for the nonnuclear-weapon states' commitment not to obtain nuclear arms in the future. The Soviet Union and United States, permanent co-chairs of the NPT negotiations in Geneva between 1965 and 1968, were initially reluctant to include provisions for disarmament in the treaty text. Article VI - a deliberately vague gesture toward future negotiations - was included in the draft NPT only once a number of states had made it clear that they would not join a treaty that formally and perpetually relegated them to second-class status. ${ }^{69}$ Committing "each of the parties" to pursue negotiations "in good faith on effective measures relating to cessation of the nuclear arms race at an early date and to nuclear

\footnotetext{
${ }^{65}$ Slavoj Žižek, The Sublime Object of Ideology (London: Verso, 2008), p. 192.

${ }^{66}$ Barack Obama, "Remarks by President Barack Obama in Prague as Delivered," Prague (April 5, 2009), available online at: https://obamawhitehouse.archives.gov/the-press-office/remarks-president-barack-obama-prague-delivered.

${ }^{67}$ Reuters, "Trump Says 'Ultimate Deal' With Putin Would Be World Without Nuclear Weapons" (July 12, 2018), available online at: https://www.reuters.com/article/us-nato-summit-trump-nuclear/trump-says-ultimate-deal-with-putin-would-be -world-without-nuclear-weapons-idUSKBN1K21ME; Donald Trump, "Remarks by President Trump and Prime Minister Abe of Japan,"Marcha-Lago (April 18, 2018), available online at: https://www.whitehouse.gov/briefings-statements/remarkspresident-trump-prime-minister-abe-japan-joint-press-conference/.

${ }^{68}$ Fumio Kishida, "Press Conference by Foreign Minister Fumio Kishida," Ministry of Foreign Affairs of Japan, Tokyo (July 11, 2017), available online at: https://www.mofa.go.jp/press/kaiken/kaiken3e_000025.html. Note the use of scare quotes.

${ }^{69}$ See Mohammed I. Shaker, The Nuclear Non-Proliferation Treaty, Vol. 2 (London: Oceana, 1980), p. 556.
} 
disarmament," Article VI of the NPT allowed all involved to frame the establishment of an unequal nonproliferation regime as temporary indignity that would be rectified through future measures of disarmament. ${ }^{70}$ The sublime object of disarmament thus glossed over the unequal nature of the emergent nuclear order, obscuring profound clashes of interest between nuclear haves and have-nots behind a "veil of good intentions."71

The great puzzle of the nuclear world, it has been suggested, is how representatives of the nuclear-weapon states have been able, over a period of several decades, to trick the leaders of nonnuclear-weapon states into believing that nuclear disarmament would actually be effected. ${ }^{72}$ The NPT, in this view, represents one of the "greatest con games of all times." 73 Yet it is a matter of record that many nonnuclear-armed leaders took the nuclear-weapon states' commitment to disarmament with a large pinch of salt already at the time of the NPT's adoption; it has always been quite plain that the nuclear-armed states are not particularly interested in abolition. ${ }^{74}$ The real puzzle, then, is not how the nonnuclear-weapon states were duped, but how the hierarchical legal structure codified by the NPT was able to survive for five decades despite common knowledge that its overarching justification - the nuclear-weapon states' impending disarmament - was a sham. The theorist Peter Sloterdijk asks the underlying question in the following way: How do ideologies survive their own unmasking? The answer, he suggests, is the cultivation by modern ideologies of an attitude of "cynical reason" - a sense that resistance is socially uncomfortable, dangerous, or will inevitably just be "dragged down by the 'power of things."'75 Accordingly, even fully "enlightened" subjects most often resign themselves to acquiescing to the dominant social practices and institutions and, by extension, to upholding the dominant ideology. ${ }^{76}$

"Cynical reason" shapes global nuclear politics in at least two ways. First, cynical subjects resign themselves to going through the motions and shun radical action in anticipation of objections from expected veto players. This obviously applies to the actions of various nonnuclear-weapon states in traditional diplomatic forums, but also to the behavior of political actors within the nuclear-armed states. As pointed out by Benoît Pelopidas, history offers several examples of high-level US and Soviet officials "who understood that the current course of nuclear policy in their country was flawed but did not speak up because they thought a third party would be reluctant to change and powerful enough to block any change. ${ }^{\prime 77}$ For example, in budget debates during the 1960s, US Secretary of Defense Robert McNamara consistently demanded funding for more nuclear weapons than he thought necessary, because "he thought he would not be credible in front of Congress had he asked for fewer. ${ }^{178}$ Tailoring one's proposals to the

\footnotetext{
${ }^{70}$ Anne Harrington de Santana, "The Strategy of Non-Proliferation," Millennium 40:1 (2011), pp. 3-19.

${ }^{71} J a n$ Ruzicka, "Behind the Veil of Good Intentions," International Politics 55:3-4 (2018), pp. 369-85.

${ }^{72}$ See e.g. Benjamin Zala, "Can the Nuclear Non-Proliferation Treaty Outrun its Double Standard Forever?" Sustainable Security (May 12, 2013), available online at: https://www.oxfordresearchgroup.org.uk.

${ }^{73}$ Epstein, The Last Chance, p. 118.

${ }^{74}$ See, for example, Caroline Fehl, "Understanding the Puzzle of Unequal Recognition," in Recognition in International Relations, eds. Christopher Daase et al. (Basingstoke: Palgrave Macmillan, 2015), p. 107.

${ }^{75}$ Peter Sloterdijk, Critique of Cynical Reason, trans. M. Eldred (Minneapolis, MN: University of Minnesota Press, 1987), pp. $5-6$.

${ }^{76}$ Sloterdijk, Critique of Cynical Reason, p. 6. See also Harrington de Santana, "Nuclear Weapons as the Currency of Power."

${ }^{77}$ Benoît Pelopidas, "A Bet Portrayed as a Certainty," in The War That Must Never Be Fought, eds. George. P. Schultz and James E. Goodby (Stanford: Hoover Institution Press, 2015), p. 53.

${ }^{78}$ Pelopidas, "The Birth of Nuclear Eternity."
} 
expected demands of a veto player has important political effects. Not only does it run the risk of misjudging the veto player's actual power and demands - and thus the real scope for action - it also fosters an endless search for the lowest common denominator, contracting the discursive space and, by extension, the realm of actions deemed responsible and mainstream at the next political junction.

Second, ideological illusions are sometimes deliberately upheld to preserve the status quo or prevent supposedly dangerous alternatives from gaining traction. In these cases, the actor projecting the illusion knows the illusion to be just that, but believes it to serve a greater purpose. An argument made by Australia's former ambassador for disarmament, Richard Butler, is instructive:

Imagine the circumstances if the United States or other nuclear-weapon states were to say: "We've been lying. We have no intention of ending our reliance on nuclear weapons. We will not fulfil our commitment under article VI of the NPT, but we will continue to expect nonnuclear weapon states to fulfil theirs of never acquiring nuclear weapons". It would be a tossup between which reaction would come faster or in larger measure - the beginning of nuclear weapons programmes in a number of countries or a major breakdown in global political relations. What is certain is that both would occur. ${ }^{79}$

It seems obvious from the passage and context that Butler himself is fully aware that the nuclear-weapon states have no intention of ending their reliance on nuclear weapons. What Butler fears is that representatives of the nuclear-weapon states would say this out loud, leading others to learn the truth already discovered by the former ambassador. Exposing the sublime object of nuclear abolition as a sham, Butler believes, would lead to "the beginning of nuclear weapons programmes in a number of countries" and a "major breakdown in global political relations." Consequently, Butler apparently sees it as his task to sustain the illusion of the nuclear-weapon states' commitment to nuclear abolition. This, in turn, logically commits him to supporting the nuclear-weapon states' preferred policy option, which is to subordinate arms control and disarmament to the supposed requirements of nuclear deterrence and allied reassurance.

\section{The Nature of Nuclear Politics}

References to "nature" and the "inherent" properties of technologies are always significant in an ideological perspective. In Sloterdijk's words, "the rudiments for ideologies of order are hidden in all naturalisms." ${ }^{80}$ Claims about nature can be used to bind or exclude people to or from a political community, justify particular arrangements, or excuse failures to realize declared goals. In the following, I discuss the ideology of nuclear order's underlying assumptions about the nature of nuclear politics.

\section{Desire}

The first naturalism of the ideology of nuclear order is the supposed "natural desire" to acquire and possess nuclear weapons. ${ }^{81}$ As Shampa Biswas points out, a natural desire to

\footnotetext{
${ }^{79}$ Richard Butler, Fatal Choice (Boulder, CO: Westview Press, 2001), p. 146.

${ }^{80}$ Sloterdijk, Critique of Cynical Reason, p. 59.

${ }^{81}$ See e.g. United Kingdom, UNGA First Committee, UN doc. A/C.1/69/PV.12. New York (October 20, 2014); Adil Sultan, Universalizing Nuclear Nonproliferation Norms (London: Palgrave Macmillan, 2019), p. 24.
} 
obtain nuclear weapons is implied by many of the central concepts with which nuclear politics is discussed. For example, strategies to seek national or human security without reliance on nuclear weapons are understood as nuclear "restraint" or "abstinence." These terms, Biswas points out, imply that the non-acquisition of nuclear weapons amounts to a form of sacrifice or curbing of natural impulses. ${ }^{82}$ Along similar lines, the field-defining concept of "proliferation" - imported from biological sciences to replace the more straightforward descriptors of "spread," "acquisition," and "dissemination" - suggests an irreversible, pathological, and self-begetting chain reaction caused by underlying forces of nature. ${ }^{83}$ Pelopidas has documented how this erroneous assumption has contributed to consistent over-predictions of the speed of the spread of nuclear weapons by nuclear experts since the 1960s. ${ }^{84}$ As discussed above, despite the fact that eight of the ten states that have ever produced nuclear explosive devices had built their first such device by the 1970s, nuclear policy pundits often make the claim that nuclear proliferation is "accelerating" 85 or that humanity has entered a new "age" of nuclear proliferation. ${ }^{86}$

The implication of the naturalism of nuclear desire is that, despite the overarching goal of a world without nuclear weapons, the best the international community can hope for in practice is to limit further nuclearization. According to Pelopidas, the assumption of universal nuclear desire "discredits disarmament moves as contrary to the 'direction of history', claiming that actions in favor of disarmament would just be utopian and therefore impossible. ${ }^{\prime 87}$ The idea that nuclearization is inevitable and irreversible consequently "leads to a focus on arms control instead of disarmament, because it only pretends to slow the pace of the movement of history and not to try to reverse it." ${ }^{88}$ This linear understanding of history often shines through in the statements of officials representing nuclear-armed states and their allies. Typically, nuclear desire and the prospect of proliferation appears in the guise of unspecified "rogue states," "terrorists," or "bad actors." As long as such actors are on the search for nuclear weapons, so goes the argument, "responsible nuclear powers" - a category critical scholars have understood as racialized, gendered, and patriarchal ${ }^{89}$ - must retain their "deterrents." In this way, nuclear desire, via "bad actors," externalizes the cause of the non-realization of the sublime object of peace and security in a world without nuclear weapons. The creation of such permanent excuses or "evils" is arguably a defining trait of ideologies; an ideology, in this view, is a "symbolic field which contains such a filler [an excuse or scapegoat] holding the place of some structural impossibility, while simultaneously disavowing this impossibility." ${ }^{\prime 90}$

\footnotetext{
${ }^{82}$ Biswas, Nuclear Desire, p. 114.

${ }^{83}$ Benoît Pelopidas, "The Oracles of Proliferation," Nonproliferation Review 18:1 (2011), pp. 297-314.

${ }^{84}$ Ibid.

${ }^{85}$ See e.g. Shultz et al., "Toward a Nuclear-Free World."

${ }^{86}$ Shultz et al., "Deterrence in the Age of Nuclear Proliferation."

${ }^{87}$ Pelopidas, "The Oracles," p. 307.

${ }^{88}$ lbid.

${ }^{89}$ Effeminate, subaltern, and racialized "others" are implicitly assumed to lack the capacity for responsibility and restraint. See Ray Acheson, "Impacts of the Nuclear Ban," Global Change, Peace \& Security 30:2 (2018), p. 247; Gusterson, "Nuclear Weapons and the Other." Race has also been argued to have played a role in the atomic bombings of Hiroshima and Nagasaki. See Sean L. Malloy, "When You Have to Deal with a Beast," in The Age of Hiroshima, eds. Michael D. Gordin and G. John Ikenberry (Princeton, NJ: Princeton University Press, 2020). Malloy finds that the role of race in nuclear politics has been underexplored in part due to a more general lack of attention to the ideological underpinnings of nuclear policy.

${ }^{90}$ Slavoj Žižek, The Plague of Fantasies (London: Verso, 2008), pp. 97-98.
} 
The assumption of an abstract and pervasive nuclear desire is intimately linked to a recurring trope in the ideology of nuclear order, namely the idea that the NPT is constantly on the verge of disintegration. In this view, a single case of proliferation or a failure by the nuclear-weapon states to implement their disarmament obligations could lead to a wave of proliferation or mass withdrawals from the NPT. ${ }^{91}$ The latter hypothesis is often implicitly invoked in the name of disarmament. ${ }^{92}$ The logic is simple: If the nuclear-armed states became convinced that they had to make a choice between disarmament and uncontrolled spread of nuclear weapons, they might opt for disarmament. But this "collapse thesis" is both empirically uncorroborated - support for the NPT is at an all-time high and the rate of proliferation has slowed over time - and arguably counterproductive for those promoting disarmament. Based on the assumption that the non-possession of nuclear weapons is a painful sacrifice that could easily be reversed, the collapse thesis upholds the notion that denuclearization is a naïve or impractical struggle against nature. In reality, only a minority of states have ever pursued nuclear armament. ${ }^{93}$

\section{Power}

The second naturalism of the ideology of nuclear order is the assumption that nuclear weapons straightforwardly and automatically bestow their possessors with supreme deterrence and blackmailing power - that nuclear arms are "ultimate" weapons and strategic game-changers. ${ }^{94}$ As Anne Harrington puts it with respect to deterrence, for more than half a century "the practice of nuclear deterrence has been treated as if it were both a natural and inevitable result of the existence of nuclear technologies." ${ }^{\prime 95}$ Already in 1963, former US Secretary of State Dean Acheson conceded that the United States had sold two ultimately harmful ideas to the world: "One was that nuclear weapons were a status symbol. [...] Secondly, if you had them, you could do anything. These were magical weapons." ${ }^{\prime 66}$ Indeed, nuclear arsenals are often referred to simply as "deterrents" without any notion of whether the weapons in question are in fact discouraging anyone from undertaking acts of aggression they otherwise would have carried out. Nuclear weapons, in this view, lend coercive power by virtue of their mere existence. Consequently, for Shultz et al., there is an "inherent limit" to the nuclear reductions the United States and Russia can undertake "if other nuclear weapon states build up their inventories or if new nuclear powers emerge." ${ }^{97}$ For another observer, "nuclear weapons cannot be stripped of their value" since their military utility stems from their material characteristics and "the competitive nature of an insecure international system." ${ }^{\prime 98}$ Nuclear disarmament, then, will inevitably imply a renunciation of something objectively valuable, especially if undertaken unilaterally.

\footnotetext{
${ }^{91}$ Pelopidas, "The Oracles."

${ }^{92}$ See e.g. United Nations, A More Secure World (New York, NY: Department of Public Information, 2004), p. 40.

${ }^{93}$ See Benoît Pelopidas, "Renunciation, Reversal and Restraint," in Routledge Handbook of Nuclear Proliferation and Policy, eds. Joseph Pilat and Nathan E. Busch (London: Routledge, 2015), pp. 337-47.

${ }^{94}$ Pelopidas, "A Bet Portrayed as a Certainty."

${ }^{95}$ Harrington de Santana, "Nuclear Weapons as the Currency of Power," p. 327.

${ }^{96}$ Dean Acheson, "The Obstacles to Partnership with Europe," Engineering and Science 26:6 (1963), pp. 11-15.

${ }^{97}$ Shultz et al., "Deterrence in the Age of Nuclear Proliferation."

${ }^{98}$ Susan B. Martin, "The Continuing Value of Nuclear Weapons," Contemporary Security Policy 34:1 (2013), p. 174.
} 
The naturalism of nuclear deterrent/blackmailing power functions to confirm the interminable utility of nuclear weapons, amplifying their attractiveness. Implying not only that disarmament is naïve but also dangerous, the naturalism of deterrent/blackmailing power bolsters the ideology's suspicion against transformative change and reinforces the imperative of safeguarding the perceived legitimacy of nuclear deterrence. For example, a common argument holds that disarmament by the "responsible," Western nuclear powers "would give countries like North Korea and Iran a dangerous blackmailing power." ${ }^{\prime 99}$ Along these lines, in 2017, US Ambassador to the UN, Nikki Haley, said the United States "would love to have a ban on nuclear weapons," but that, unfortunately, "in this day and time, we can't honestly say that we can protect our people by allowing the bad actors to have them and those of us that are good trying to keep peace and safety not to have them." ${ }^{100} \mathrm{~A}$ number of critics have argued that such claims reflect a considerable exaggeration of both the automatic deterrent power of nuclear weapons and the utility of such weapons as instruments of blackmail. ${ }^{101}$ For example, the nuclear and conventional military superiority of the United States did not compel the Afghani, Serbian, or Iraqi governments to give in to US demands in the late 1990s and early 2000s, and the nuclear "deterrents" of the United Kingdom and Israel failed to deter the outbreaks of the Falklands and Yom Kippur wars, respectively. There is no doubt that nuclear arms are immensely destructive weapons, yet it is hardly the case that the presence of nuclear weapons automatically causes either "deterrence," "blackmail," or the emotional states associated with those phenomena. There is little evidence that nuclear weapons provide their possessors with coercive advantage. ${ }^{102}$

The naturalism of the power of the "ultimate" weapon gives rise to an acute suspicion of "unstable" strategic relations, a suspicion that is reflected in all the nuclear arms limitation agreements concluded between the United States and the Soviet Union/ Russia. As David Mutimer points out, the arms control school's emphasis on balance "suggests that the intentional use of nuclear weapons is actually quite unlikely, but rather the danger is of an unstable balance toppling into war."103 In this perspective, the problem is not nuclear weapons per se, but nuclear excess or imbalance. By extension, Mutimer argues, the arms control paradigm "has produced nuclear weapons as a means to security, a bulwark against what is risky and inconvenient." ${ }^{104}$ In Anne Harrington's words, the dominant policy discourse fetishizes nuclear weapons as the "currency of power," bolstering their prestige value. ${ }^{105}$

\section{The Ideological Apparatus of Nuclear Order}

According to Louis Althusser's theory of ideology, obedience to political arrangements is produced through two main "apparatuses." ${ }^{106}$ First, the "repressive apparatus" enforces

\footnotetext{
${ }^{99}$ Thérèse Delpech, Nuclear Deterrence in the 21st Century (Santa Monica, CL: RAND, 2012), p. 56.

${ }^{100}$ Noland D. McCaskill, "UN Ambassador Haley Opposes International Ban on Nukes," Politico (March 27, 2017), available online at: https://www.politico.com/story/2017/03/nikki-haley-united-nations-nuclear-weapons-ban-236544.

${ }^{101}$ See e.g. Richard N. Lebow, "Deterrence: Then and Now," Journal of Strategic Studies 28:5 (2005), pp. 765-73.

${ }^{102}$ Harrington de Santana, "Nuclear Weapons as the Currency of Power"; Pelopidas, "A Bet Portrayed as a Certainty"; Ward Wilson, "The Myth of Nuclear Deterrence," Nonproliferation Review 15:3 (2008), pp. 421-39.

${ }^{103}$ David Mutimer, "From Arms Control to Denuclearization," Contemporary Security Policy 32:1 (2011), p. 60.

${ }^{104}$ Ibid., 72. Emphasis added.

${ }^{105}$ Harrington de Santana, "Nuclear Weapons as the Currency of Power."

${ }^{106}$ Althusser, On the Reproduction of Capitalism.
} 
compliance through the straightforward employment of coercive power. On the national level, the state enforces compliance through the police, bureaucracy, and, occasionally, the military. In international politics, powerful states have at their disposal a more limited but still formidable repertoire of repressive means, including the use of armed force and economic sanctions and inducements. Such means have occasionally been employed in the service of policing the nuclear order. Suspected (or supposed) proliferators have been subjected to economic sanctions, sabotage, and, in the case of Iraq, invasion and occupation. ${ }^{107}$ Repressive means have also been employed to foil disarmament initiatives. For example, nuclear-weapon states have on several occasions been reported to have threatened developing states with canceled aid, trade deals, or technology transfers to prevent them from voting for disarmament resolutions deemed too radical. ${ }^{108}$

Second, the "ideological apparatus" fosters compliance with political arrangements by "interpellating" actors into specific subject positions, that is, by constituting subjects' roles, identities, and worldviews. In contrast to the repressive apparatus, the ideological apparatus elicits voluntary, internalized compliance - what La Boétie called "voluntary servitude" - with the political arrangement upheld by the ideology. ${ }^{109}$ On the national level, ideologies are propagated through the media, religion, cultural events, and the educational system. Many of the same vehicles of interpellation exist in international life. The most powerful states wield significant influence through their dominance of international institutions, cultural exports, media channels, and academic institutions. ${ }^{110}$

\section{The Nonproliferation Complex}

The ideological apparatus of nuclear order operates through two main branches. The first is constituted by the web of think tanks, university programs, NGOs, commissions, and expert groups Campbell Craig and Jan Ruzicka term the "nonproliferation complex." ${ }^{111}$ Made up of dozens of (mostly European and North American) organizations engaged in the business of analyzing and reducing nuclear dangers, the nonproliferation complex has dominated the discourse on nuclear risks and governance for decades. ${ }^{112}$ The members of the complex frequently promote divergent policy options and engage in lively debates about contemporary issues. However, these debates usually take place within a narrow spectrum, with the main topics of contention being how Western governments should deal with North Korea and Iran, details about the US-Russian strategic nuclear relationship, and whether or not specific nuclear-weapon procurements ("modernization") ought to be pursued.

The conservative bent of mainstream nuclear-policy analysis, which has been pointed out by several scholars, ${ }^{113}$ is discernible at the levels of language, agenda-setting, and policy. First, with respect to language, critical analysts have long argued that mainstream nuclear-policy

\footnotetext{
${ }^{107}$ John Mueller, Atomic Obsession (Oxford: Oxford University Press, 2009).

${ }^{108}$ See e.g. Kate Dewes and Robert Green, "The World Court Project," Canadian Foreign Policy Journal 7:1 (1999), p. 66.

${ }^{109}$ Etienne de La Boétie, Discourse on Voluntary Servitude (Cambridge: Hackett, 2012 [1576]).

${ }^{110}$ See Michael Barnett and Raymond Duvall, "Power in International Politics," International Organization 59:1 (2005), pp. 39-75.

${ }^{111}$ Campbell Craig and JanuaryRuzicka, "The Nonproliferation Complex," Ethics and International Affairs 27:3 (2013), pp. 329-48.

${ }^{112}$ Craig and Ruzicka, "The Nonproliferation Complex," p. 329.

${ }^{113}$ See e.g. Pelopidas, "The Oracles"; Neil Cooper, "Putting Disarmament Back in the Frame," Review of International Studies 32:2 (2006), pp. 353-76.
} 
analysis relies on a series of metaphors, euphemisms, and technical terms that are either "reversified" - that is, they denote the opposite of their original meaning ${ }^{114}$ - or "portray nuclear concepts in a 'neutral' or positive way." ${ }^{115}$ Examples include the term "deterrent" to describe offensive nuclear forces, "modernization" to describe the rebuilding of nuclear arsenals, "nuclear exchange" to describe nuclear war, and "nuclear umbrella" or "insurance policy" to describe technologies of nuclear-threat making. This rhetoric of "nukespeak" has been attentively analyzed by several scholars and will not be further explored here. ${ }^{116}$

Second, on the level of agenda-setting, the nonproliferation complex has been argued to view the world through the gaze of the governments of the established (Western) major powers. Paying limited attention to the dangers inherent to the status quo, or to the damage already wrought by nuclear testing, ${ }^{117}$ the nonproliferation complex offers considerable attentiveness to the potential dangers of change, be it through unbalanced deterrence relations, nuclear proliferation, or technological advances. ${ }^{118}$ According to one observer, nuclear studies is plagued by considerable self-censorship and overconfidence in the manageability of nuclear weapons and their attendant risks. ${ }^{119}$ According to another, there is widespread acceptance in the community "of what constitutes 'serious nuclear scholarship and political theorizing', and what, conversely, does not." Consequently, most disarmament analysts "avoid critical engagement with the theory and practice of nuclear deterrence" and "forfeit the challenge of formulating alternative theoretical models that veer off from the expected course of reasoning." ${ }^{120}$ The gaze of the powerful also seeps into media coverage. Of the 728 articles published in the New York Times between 2017 and 2019 that contained the phrase "nuclear weapon(s)," just over two thirds concerned Iran and/or North Korea - the first being a nonnuclear-weapon state and the second the holder of the world's smallest nuclear arsenal. ${ }^{121}$ Despite soaring spending on nuclear arms far closer to Midtown, involving far larger and more destructive arsenals, only 30 articles (4\% of the total) mentioned ongoing "modernization" programs or arms racing involving the United States and other established nuclear powers. As discussed elsewhere in this article, under the ideology of nuclear order, the primary concern is always with change or perceived disruptions to the status quo. This focus is enabled, in part, by an intellectual tradition that neglects the role of contingency and luck in history and society. As one scholar puts it, analysts of international security and history invariably construct causal chains that appear to have led ineluctably to outcomes that in reality were highly contingent. ${ }^{122}$ The status quo can thus be presented as the best or even only possible outcome - a stance sometimes described as panglossism. ${ }^{123}$

\footnotetext{
${ }^{114}$ Kjølv Egeland and Benoît Pelopidas, "European Nuclear Weapons? Zombie Debates and Nuclear Realities," European Security (early view, 2020).

${ }^{115}$ Edward Schiappa, "The Rhetoric of Nukespeak," Communication Monographs 56:3 (1989), pp. 253-72.

${ }^{116}$ See e.g. Carol Cohn, "Sex and Death in the Rational World of Defense Intellectuals," Signs 12:4 (1987), pp. 687-718; Claire Duncanson and Catherine Eschle, "Gender and the Nuclear Weapons State," New Political Science 30:4 (2008), pp. 545-63.

${ }^{117}$ See e.g. Tilman A. Ruff, "The Humanitarian Impact and Implications of Nuclear Test Explosions in the Pacific Region," International Review of the Red Cross 97:899 (2015), pp. 807-8.

${ }^{118}$ Biswas, Nuclear Desire, Chapter 2.

${ }^{119}$ Benoît Pelopidas, "Nuclear Weapons Scholarship as a case of Self-Censorship in Security Studies," Journal of Global Security Studies 1:4 (2016), pp. 326-36.

${ }^{120}$ Meyn, "Realism for Nuclear-Policy Wonks," pp. 115-16.

${ }^{121}$ The statistic includes all news and opinion pieces but excludes obituaries.

${ }^{122}$ Richard Ned Lebow, "Counterfactuals and Security Studies," Security Studies 24:3 (2015), p. 406.

${ }^{123}$ Ken Booth, Theory of World Security (Cambridge: Cambridge University Press, 2007), pp. 397-98.
} 
Third, on the policy level, the nonproliferation complex routinely functions as a break on disarmament initiatives while championing, or at any rate tolerating, coercive counterproliferation efforts. The social role fulfilled by the nonproliferation complex, then, is that of a "discourse police" which ensures that policy proposals conform with the dominant ideology. ${ }^{124}$ In the case of the Iraq sanctions and 2003 invasion, the rhetorical resources of the nonproliferation complex provided the US and UK governments with a liberal justification for war. "Caught in a trap of their own making, few prominent members of the complex openly opposed the war during the tumultuous days of 2002-2003," Craig and Ruzicka assert. ${ }^{125}$ In the case of the indefinite extension of the NPT in 1995, the nonproliferation complex offered rhetorical support to the long-term goal of disarmament, but lobbied heavily in favor of the nuclear-weapon states' preferred option of indefinite extension without meaningfully strengthening the NPT's disarmament provisions. ${ }^{126}$ Another example is the overwhelming opposition of the nonproliferation complex to the German coalition government's 2009 pledge to work for the removal of US nuclear weapons from German soil. For instance, the London-based Center for European Reform published a briefing note by three former UK and US officials-turned-experts that strongly rebuked Germany for wanting "others to risk nuclear retaliation on its behalf," insisting that disarmament would need to take place through "carefully orchestrated moves, which avoid destabilizing existing alliances." ${ }^{127}$ The Foundation for Strategic Research in Paris published a report arguing that the German initiative, if put into action, would have "damaging political consequences in terms of alliance cohesion" and provide a source of "considerable satisfaction in Moscow."128 Unsurprisingly, the German government ended up backing down and the deployments were kept in place. A further example is the nonproliferation complex' inattention, and often outright opposition, to the TPNW and the movement that led to its adoption - quite contrary to what one might expect from a network of organizations nominally in favor of disarmament. Afflicted by what Nick Ritchie has referred to as nuclear "ordering anxiety," ${ }^{129}$ influential members of the complex prophesized that a ban on nuclear weapons would distract from more "pragmatic" approaches to disarmament, destabilize alliances, provide dangerous opportunities for "forum shopping" and an institutional race to the bottom, put a smile on various dictators' faces, or engender unwelcome "polarization" in the disarmament community. ${ }^{130}$ This discourse allowed nonnuclear US allies such as Norway, Germany, and Japan to argue that they opposed the new treaty not because it would challenge their extended nuclear deterrence postures or the nuclear status quo, but because it was not a good enough disarmament measure. ${ }^{131}$

\footnotetext{
${ }^{124}$ See Iver Neumann, "Returning Practice to the Linguistic Turn," Millennium 31:3 (2002), pp. 627-51.

${ }^{125}$ Craig and Ruzicka, "The Nonproliferation Complex," p. 344.

${ }^{126}$ lbid.

${ }^{127}$ Franklin Miller, George Robertson, and Kori Schake, "Germany Opens Pandora's Box," Center for European Reform (February 2020), p. 2.

${ }^{128}$ David Yost, "US Extended Deterrence in NATO and North-East Asia," in Perspectives on Extended Deterrence, ed. Bruno Tertrais (Paris: Fondation pour la recherche strategique, 2010), p. 20.

${ }^{129}$ Ritchie, "A Hegemonic Nuclear Order," p. 410.

${ }^{130}$ See Kjølv Egeland, "Banning the Bomb: Inconsequential Posturing or Meaningful Stigmatization?" Global Governance 18:1 (2018), pp. 11-20.

${ }^{131}$ See e.g. Germany, Open-Ended Working Group on Nuclear Disarmament, Geneva (February 24, 2016), available online at: http://www.reachingcriticalwill.org/images/documents/Disarmament-fora/OEWG/2016/Statements/25Feb_ Germany.pdf.
} 


\section{Rituals and Diplomatic Practice}

The most formidable branch of the ideological apparatus of nuclear order is the institutional architecture of nuclear diplomacy: the NPT review cycle, the UNGA First Committee, the CD, the IAEA, the UN Disarmament Commission, the P5 process, and other institutionalized gatherings. Through a running series of meetings, conferences, roadmaps, and action plans that in reality have little if any effect on actual policies, nuclear diplomacy is presented as a dynamic movement toward the realization of the sublime object of nuclear abolition. But, as Ursula Jasper maintains, the ritualized functioning of the diplomatic process, in particular the NPT review cycle, contributes to a tacit, incremental strengthening of the status quo. Participation in the diplomatic process "resembles the performance of a pilgrimage or the 'High Mass', which reifies and reproduces the institution as such, rearticulates the underlying shared knowledge and constructs and reaffirms the boundaries between inside and outside as well as between the different classes of treaty members." ${ }^{132}$ Giving nonnuclear-weapon states and critical NGOs an opportunity to voice criticisms against the major powers' policies, the NPT review cycle functions as a mechanism for venting spleen and soaking up dissent. ${ }^{133}$ Although many nonnuclearweapon states routinely use NPT meetings as arenas for contesting the nuclear-armed states' track record on disarmament, those very arenas help interpellate some states as high-status, active, and "nuclear" and others as low-status, passive, and "nonnuclear." The NPT itself is drafted on the premise that nuclear weapons are dangerous but also immensely useful, powerful, and at least temporarily legitimate for a select group of major powers. And as discussed above, the propagation of an ideology does not depend on what actors privately believe, but on what they do in practice.

A crucial mechanism of the incremental strengthening of the status quo produced by the NPT review cycle is the enormous importance attached to "consensus" at review conferences. Under the ideology of nuclear order, the health of the nonproliferation regime depends on regular injections of legitimacy through the periodic adoption of final documents at NPT review conferences. A failure to adopt such documents is portrayed as a sign of dangerous division and disorder. Consequently, at every other NPT review conference, parties have been eager to reach consensus on almost any terms. For example, fears about the potential demise of the NPT in the 1990s led in 2000 to the conclusion of an NPT review conference final document stipulating 13 "practical steps" toward disarmament. The predictable unwillingness of nuclear-weapon states to implement these steps in practice led to the equally predictable failure of the 2005 conference to reach consensus on a new final document. Five years later, fears that the regime was unraveling led to the adoption in 2010 of a final document containing largely the same commitments as the document adopted in 2000. Repeating the pattern once more, the 2015 Review Conference unsurprisingly failed to achieve consensus, setting up the 2020 conference (postponed until 2021) for a repeat of 2000 and 2010 (though it is unclear how the adoption of the TPNW will affect this dynamic). Through this cycle of intermittent "agreement," the nuclear-weapon states and their allies can claim to be acting in good faith, and the cyclical NPT review is portrayed as a "process" geared toward the sublime object of peace and security in a world without nuclear weapons.

\footnotetext{
${ }^{132}$ Jasper, "Dysfunctional, but Stable," p. 51.

${ }^{133}$ Ruzicka, "Behind the Veil."
} 


\section{Ideological Subversion and the Treaty on the Prohibition of Nuclear Weapons}

As discussed above, the standard mechanism through which ideologies legitimize unequal social arrangements is the promotion of formal rules, principles, or sublime objects that disguise relationships of domination behind universal pretentions and a nominally shared vision of the future. ${ }^{134}$ The trick, one theorist argues, is the simultaneous existence of a set of informal, unspeakable rules that stipulate boundaries and exceptions to the formal principles. ${ }^{135}$ Stalinism, for example, was formally committed to free speech. However, it would have been clear to everyone that this formal right to free speech was bounded by a stronger, implicit prohibition against criticizing Stalin and his Party. And the only thing that could be more subversive than violating the implicit prohibition on criticizing Stalin would be to acknowledge the existence of this prohibition in public. $^{136}$

The ideology of nuclear order is similarly structured by formal and informal rules. The formal rules of the prevailing nuclear order are those related to nonproliferation, disarmament, and nuclear abstinence. In Walker's words, the established nuclear order is "unambiguously dedicated, for practical as well as moral reasons, to the elimination of nuclear weapons." ${ }^{137}$ It is clear, however, that these formal ideals are in practice heavily constrained by a deeper set of informal rules related to the major powers' ostensible "special rights" as custodians of international order. ${ }^{138}$ Crucially, the ideology of nuclear order implicitly awards the NPT nuclear-weapon states an implicit right to possess nuclear weapons and, by extension, to practice nuclear deterrence. Thus, while violations of the nonproliferation norm will invariably invite economic sanctions, media sensationalism, public condemnation, and/or military counter-proliferation operations, the norm of disarmament is non-enforceable and endlessly conditional. The ideology also discourages nonnuclear-weapon states from taking a too active role in the shaping of international norms applicable to nuclear weapons, reserving agency and "managerial responsibility" to the nuclear-weapon states. ${ }^{139}$ Tellingly, prior to the development of the TPNW, Britain, Russia, and the United States were the "depositary powers" of all the legally effective global treaties concerned with nuclear weapons: the NPT, the Partial Nuclear-Test-Ban Treaty, the Seabed Arms Control Treaty, the Outer Space Treaty, and the IAEA Statute (the United States is the sole depository of the latter).

The subversive potential of the TPNW owes to the ban movement's deliberate clash with these unwritten, deeper rules of nuclear order. Not only did the movement contest the major powers' supposed entitlement to possess nuclear weapons, it also contested their right to determine how and when treaties are negotiated. Until the adoption of the TPNW, these informal rules had largely been heeded; since the 1960s, the representatives of neutral and nonaligned states had for the most part limited their advocacy to calling on the nuclear-weapon states to implement existing agreements, thus leaving all agency in

\footnotetext{
${ }^{134} \mathrm{Cf}$. Giddens, Central Problems, pp. 193-96.

${ }^{135}$ Slavoj Žižek, The Universal Exception (London: Bloomsbury, 2014), p. xvi.

${ }^{136}$ Slavoj Žižek, "What Can't You Say?," New Statesman (May 28, 2015), available online at: https://www.newstatesman. com/politics/2015/05/what-can-t-you-say-stephen-fry-slavoj-i-ek-elif-shafak-and-more-say-unsayable.

${ }^{137}$ Walker, "Nuclear Order and Disorder," p. 722.

${ }^{138}$ Hedley Bull, The Anarchical Society. 3rd edition (Basingstoke: Palgrave, 2002), p. 196.

${ }^{139}$ Ibid.
} 
the hands of the powerful. As one set of commentators put it in 2013, the ban-treaty movement offered an opportunity for nonnuclear states to transcend their traditional role of "moralizing spectators." ${ }^{140}$ Of course, at the level of formal or explicit ideological content, the ban-treaty movement merely rearticulated the existing order's formal ideals of nuclear abstinence and war prevention, leading one scholar to ask whether the ban movement actually offered anything beyond a tired rehearsal of well-known disarmament arguments and clichés. ${ }^{141}$ Through the lens of ideology critique, however, it becomes clear that the novelty of the TPNW initiative was not its anti-nuclear rhetorical content, but its institutional form as a practical treaty-making process Ideology resides in (in)action, not beliefs.

Justified as an initiative to implement the obligation contained in Article VI of the NPT to negotiate effective measures for nuclear disarmament, the pursuit and adoption of the TPNW instantiated what has been called a strategy of "subversive overconformism." ${ }^{142}$ By taking the formal rules literally, the ban-treaty proponents subverted the prevailing nuclear order's unwritten rule that the "special rights" of the nuclear-weapon states should not be challenged. Of course, the TPNW cannot straightforwardly force the nuclear-armed states to give up a single nuclear weapon. However, the TPNW provides a focal point for reconstructing the prevailing nuclear order from a system in which certain states possess nuclear weapons with "absolute legitimacy," as put by the Russian delegation to the UNGA in $2016,{ }^{143}$ to one in which certain states possess indiscriminate weapons in defiance of international legal norms. If one accepts the idea that politics is downstream from culture and norms, ${ }^{144}$ the second system would appear more likely to foster disarmament than the first. For ban-treaty supporters, the immediate challenge is thus to reconcile their ambition to embed the TPNW in the existing (hierarchical) nonproliferation and disarmament framework and their strategy of contesting the status quo. Along these lines, Laura Considine argues that "TPNW supporters should consider the extent to which they are willing to withdraw the performative acts of legitimation that uphold the current regime in order to consolidate an emerging prohibition norm." ${ }^{145}$

The TPNW's subversive thrust is two-fold: First, as discussed above, the adoption of an unconditional prohibition on nuclear weapons takes the existing norm of abstinence to its logical conclusion, undermining the existing order's implicit bestowal of "special rights" on a select group of states. Second, the pursuit and adoption of a treaty banning nuclear weapons has compelled the nuclear-weapon states to step out from behind the veil of good intentions to engage in naked attempts at pressuring their allies and other states not to join the treaty. In this way, the supporters of the

\footnotetext{
${ }^{140}$ Gro Nystuen and Stein-Ivar L. Eide, "Wanted: Resolute Normative Leadership," European Leadership Network (September 5, 2013), available online at: https://www.europeanleadershipnetwork.org/commentary/wanted-resolutenormative-leadership/.

${ }^{141}$ Laura Considine, "The 'Standardization of Catastrophe'," European Journal of International Relations 23:3 (2017), pp. 681-702. Some analysts have identified the TPNW as an expression of the same trend as the "four horsemen" and Global Zero initiative. My analysis suggests that the latter two are expressions of the ideology of nuclear order while the former is an overt challenge to it. Cf e.g. Peoples, "Redemption and Nutopia," p. 222.

${ }^{142}$ Žižek, Plague of Fantasies, p. 221.

${ }^{143}$ Russia, UNGA First Committee. UN doc. A/C.1/71/PV.22. New York (October 27, 2016).

${ }^{144} \mathrm{Cf}$. Martha Finnemore and Kathryn Sikkink, "International Norm Dynamics and Political Change," International Organization 52:4 (1997), pp. 887-917.

${ }^{145}$ Laura Considine, "Contests of Legitimacy and Value," International Affairs 95:5 (2019), p. 1092.
} 
TPNW have shone a light both on the nuclear-armed states and most of their allies' de facto hostility to changeand on the hegemonic practices that keep the status quo in pace. Perhaps it is true that "the first gesture of liberation is to force the master to act as one." 146

\section{Conclusion}

The ideology of nuclear order has provided the dominant intellectual and institutional framework for global nuclear politics since the 1960s. The solution to the nuclear predicament, so goes the argument, is to chart a "third way" between unrestrained nuclear anarchy, on the one hand, and decisive efforts toward comprehensive nuclear disarmament as a near-term objective, on the other. At the formal level, the ideology presents nuclear disarmament as imperative, but simultaneously as a long-term vision - a sublime object - subordinate to the supposed requirements of deterrence. The ideology is further marked by a puzzling combination of despair about the course of nuclear history - risks associated with the status quo are frequently conceived as unacceptably high and/or increasing - and optimism about managerial arms control proposals that have already been promoted, to little or no avail, for decades. The inability of mainstream nuclearpolicy analysis to come up with novel recommendations and answers, I have argued, owes to the ideology underlying assumptions or "naturalisms." If proliferation is inevitable and nuclear weapons natural and legitimate instruments of power, the only option is to protect the status quo and limit further nuclearization.

To sweeten the explicit legalization of a hierarchical nuclear order in the 1960s, the Cold War superpowers acquiesced to the adoption of a general commitment to future nuclear disarmament. Of course, it was clear to everyone that the nuclearweapon states' support for this goal was at best highly conditional and hortatory. Many nonnuclear-weapon states thus immediately began to push for active measures of disarmament, using the NPT review cycle as their main platform for holding the nuclear-armed states' feet to the fire. However, by voicing their criticisms within an institutional setting predicated on a legally enshrined distinction between "nuclear" and "nonnuclear" states, these advocates of disarmament contributed to a tacit strengthening of the status quo, including by allowing leaders of the nuclearweapon states to argue that their countries enjoyed an institutionally ordained status as "nuclear-weapon states" and attendant "right to possess nuclear weapons."147 Adopting an unconditional ban on nuclear arms, the supporters of the TPNW have now sought to contest the ideology of nuclear order and build a new vision of nuclear politics. While the long-term effects of the initiative are difficult to judge, the TPNW has clearly disturbed the existing power structures. Not only does the nucleararmed states' opposition imply that the strategy of stigmatization has merit, their crass attempts at discrediting the TPNW process and policing the status quo bring the political fault lines underpinning the nuclear order to the fore. Acknowledging these fault lines remains a prerequisite for any change.

\footnotetext{
146 Žižek, "What Can't You Say?".

${ }^{147}$ Tony Blair, House of Commons - Hansard (February 21, 2007), column 260.
} 


\section{Acknowledgments}

For f eedback and help, I am gratef ul to Benoît Pelopidas, Maitreyee Kishor, Sanne Vershuren, Marianne Egeland, Nari Shelekpayev, and the journal's anonymous reviewers.

\section{Disclosure statement}

No potential conflict of interest was reported by the author(s).

\section{Funding}

This project has received funding from the European Union's Horizon 2020 research and innovation programme under-grant-agreement-No 8417.64 (SNNO),-Marie-Skłodowska-Curie Actions.

\section{ORCID}

Kjølv Egeland (D) http://orcid.org/0000-0001-9818-698X 